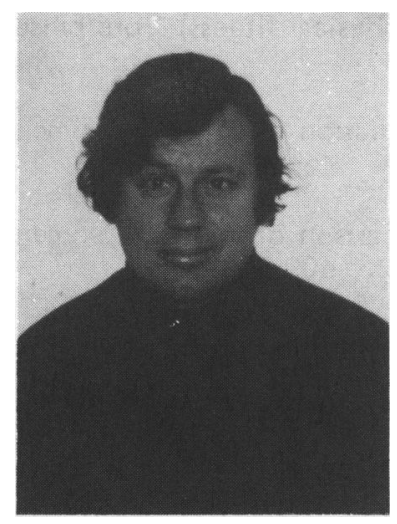

R. Grogan
RUN, PHEIDIPPIDES, RUN!

\section{THE STORY OF THE BATTLE OF MARATHON}

\author{
R. GROGAN, MBBS
}

\section{St. Vincent Place, Albert Park 3206, Australia}

\section{INTRODUCTION}

The Battle of Marathon has been described by Creasy as one of the fifteen battles which were turning points ir. our history. It occurred in $490 \mathrm{BC}$ between Greece and Persia as part of the so-called Persian Wars.

However, we are interested in it as the origin of the name of the longest running distance in the Olympic programme and as the event regarded by many distance runners as the ultimate challenge in endurance. It may well be that no run such as the Marathon run ever occurred in ancient times and, if it did, then it certainly was not 26 miles and 385 yards.

\section{GEOGRAPHY AND BACKGROUND HISTORY}

The Greek peninsula is the southernmost extremity of the Balkan land mass. It is a land of hard limestone mountains separated by deep valleys, which eventually resulted in the formation of small economic political units, and surrounded by many harbours, which helped lead to a homogenous maritime nation. It is cut almost in two by the Corinthian gulf. To the east are the islands of the Aegean Sea and to the south is the island of Crete.

The first known civilisation in the area was the Minoan civilisation of Crete which dominated the Aegean from 1600-1400 BC. This was gradually absorbed into the culture of the mainland and then superceded by a brilliant civilisation based on the city of Mycenae (1600-1200 BC). The last of several invasions from the north occurred about $1100 \mathrm{BC}$ when the Dorians (a far less civilised race) left the mountains of Epirus and pushed their way south to the Pelopennesus peninsula and Crete.

Between 1200-750 BC the Greek world passed through a Dark Age. In this period each city with its surrounding hamlets and farms became a separate social unit. Borders tended to become fixed along natural geographical boundaries and if these lines were defens- ible the city and its surrounding countryside eventually evolved into an independent community, i.e., a city state.

Although the city states maintained their autonomy they pursued a common course of political development. Some unification of the city states took place and between the 8th and 6th centuries BC the two dominant powers became Athens and Sparta. Each of these united its weaker neighbours into a league, or confederacy, under its control.

In the wake of political and economic strength came a flowering of Hellenic culture. Other important factors which led to a united Greek ethos were a common language and a common religion. As part of the observance of their religion the Greeks held four national festivals, called games - the Olympian, Isthmian, Pythian and Nemean Games.

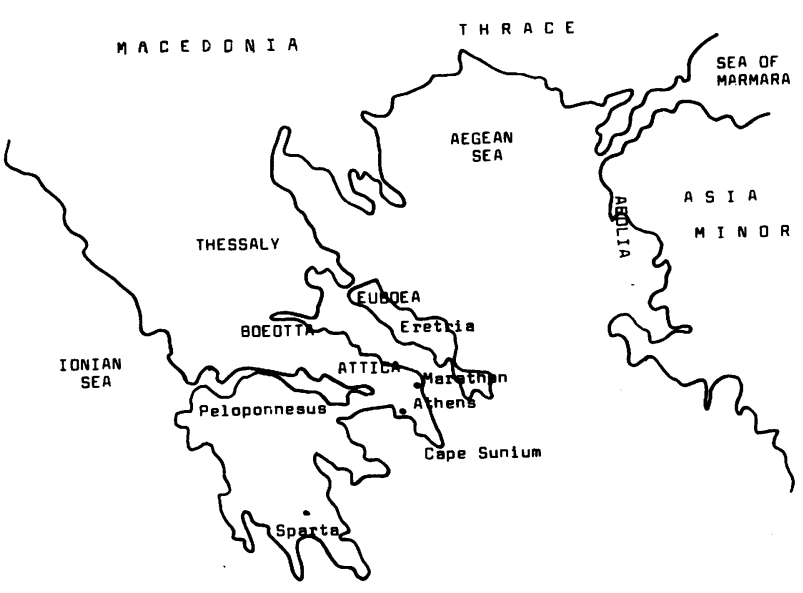

Fig. 1. The Greek world. 


\section{THE FORMATION OF IONIA}

Athens was able to resist the Dorian invasion because it was situated on a natural fortress, the rocky Acropolis. Refugees from the other Mycenaean cities flocked to Athens and the surrounding countryside of Attica. Soon the population grew too large for the comparatively limited space available; hence, in about 100 BC emigration from the area began. Greeks sailed out into the Aegean to find new homes on the islands and on the western coast of Asia Minor. These colonies in and around the Aegean Sea came to be called Ionia.

In this area the soil was rich, the coastline well provided with harbours and the frequent rivers allowed passage inland for trade and expansion. As a result of these factors the colonists prospered. They were not always welcomed by the native population and so they fortified themselves in walled towns. These precautions eventually stood them in good stead, for they were soon menaced by the Cimmerians and the Lydians (who had supplanted the Hittites) who were the rulers of Asia Minor.

\section{IONIA BECOMES PART OF THE PERSIAN EMPIRE}

For many centuries the Greek colonies on the coast lived in peace. However in the first half of the 7th century BC the Lydians attacked the cities as part of

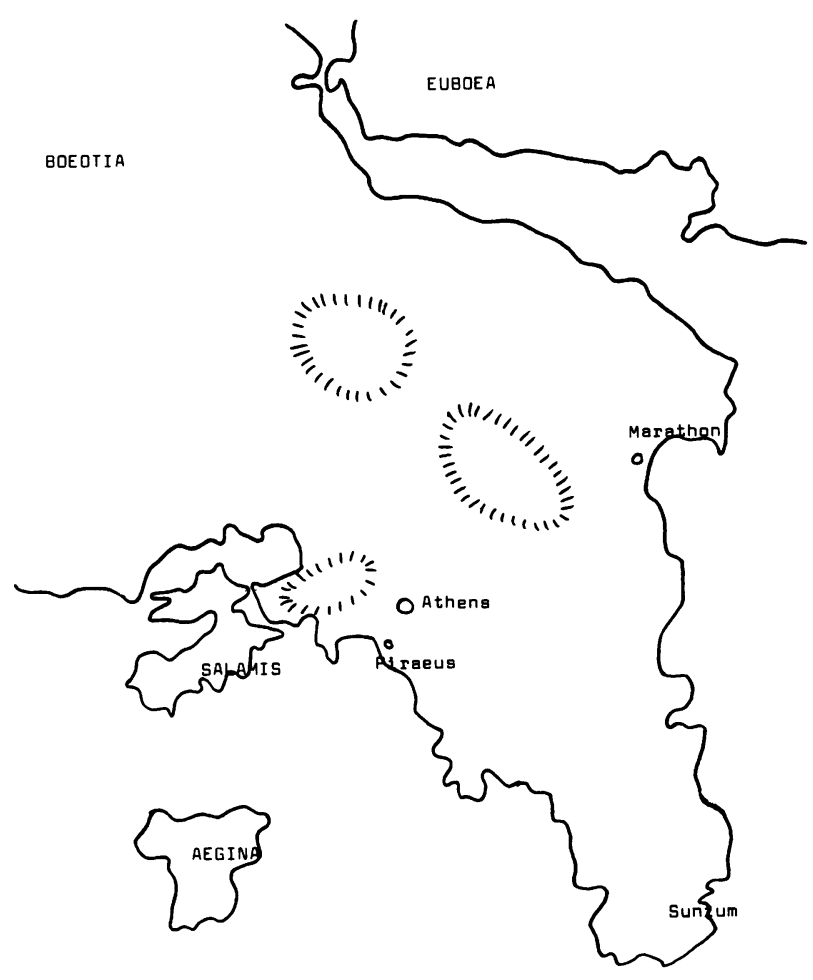

Fig. 2. Attica and surroundings. the expansion of their empire. Later Lydian kings allowed the Greeks to have autonomy, although not complete freedom.

In 546 BC Croesus, the last of the Lydian kings, was overthrown by Cyrus the Great, King of Persia. Thus the Greek cities in Asia and the coastal islands entered the Persian Empire. The Persians did not allow their new subjects to retain their autonomy. They made the local tyrants (i.e. rulers) subordinate to Persian provincial governors (satraps) and forced the lonians to pay tribute to the Empire and perform military service. For a time the Ionians submitted, but, in $499 \mathrm{BC}$ assisted by Athens and Eretria, they revolted against the Persian rule. They were at first successful but in 493 BC Darius I put down the revolt, re-established absolute control over the lonians and swore to exact revenge on their parent states.

The next year Mardonius (who was the son-in-law of Darius) led a punitive expedition against the Greek States. He subdued Thrace and Macedonia, but most of the ships were wrecked rounding Mount Athos and they were forced to return home.

At the same time Darius sent heralds to all the citystates requiring tokens of submission (i.e. earth and water). Most states complied, but Athens and Sparta both refused, slaying the Persian heralds as a gesture of defiance.

Darius, enraged by this gesture, as well as by the fate of the previous fleet, prepared a second expedition (under the control of Datis and Artaphernes, as Mardonius was wounded), consisting of 600 ships and a large army.

This set sail in $490 \mathrm{BC}$ and sailed directly across the Aegean (compared with the circular land-hugging route taken by the previous expedition) to subdue the islands and punish Eretria and Athens for having intervened in the Ionian revolt.

\section{THE STAGE IS SET FOR THE BATTLE OF MARATHON}

The Persians mastered Eretria and then sailed for Attica. The part of Attica nearest Eretria and also the best ground for cavalry to manoeuvre in was at Marathon.

The bay of Marathon was a natural landing site as it was surrounded by steep hills but opened southwards towards Athens. The Persians disembarked along the Schoenia, a marshy area which was protected by the Cynosura promontory against both storm and military interference. By not landing further south the Persians gave the Athenians the chance to cover the opening of the plain toward Athens. 


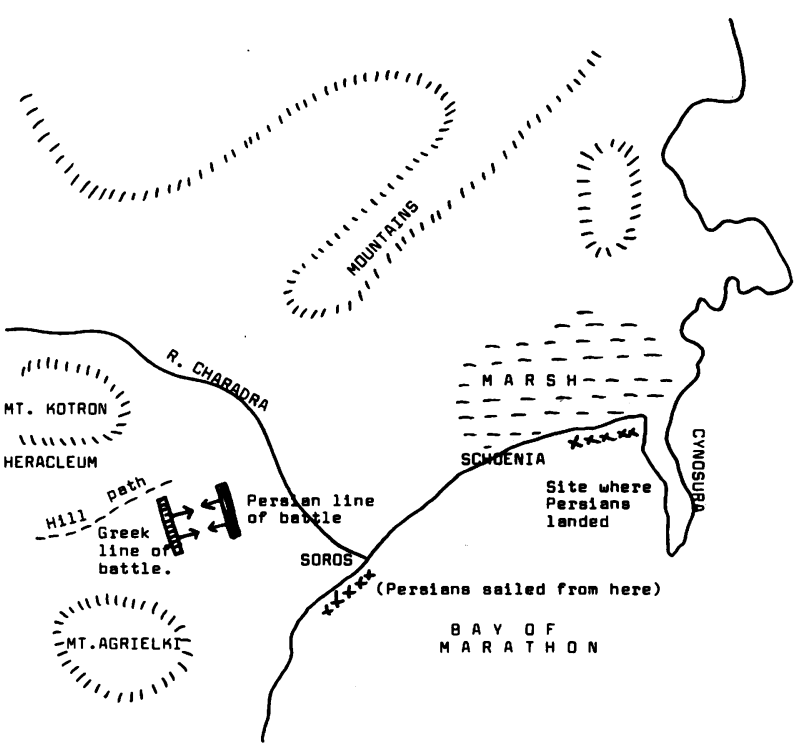

Fig. 3. Battle of Marathon.

As soon as the Athenians heard that the Persians had arrived at Marathon they hurried to meet the invading army. The Athenian troops were led by Miltiades whose father was one of only two men ever to win the chariot race at the Olympic Games three times.

\section{PHEIDIPPIDES' RUN}

Before they left the city the Athenians sent off a message to Sparta requesting assistance. The messenger was an Athenian named Pheidippides, a well trained long distance runner. Whilst running to Sparta he met the god Pan on Mount Parthenius above legia. Pan told him to ask the Athenians why they paid no attention to him, in spite of his friendliness towards them, and because of his usefulness to them in the past. Later, when he returned, the Athenians believed Pheidippides, and when their affairs were once more in order, they built a shrine to Pan under the Acropolis (this myth or incident, involving Pan, may have been added to the story centuries later).

Pheidippides continued on over the mountains and reached Sparta (a distance of $\mathbf{1 4 0}$ miles) the next day and delivered his message. "Men of Sparta, the Athenians ask your help and not stand by whilst the most ancient city of Greece is crushed and subdued by a foreign master; for even now Eretria has been enslaved Greece is the weaker by the loss of one fine city."

The Spartans, although moved by the appeal and willing to send help, were unable to offer it promptly because they did not wish to break their law (they were celebrating the festival of Carnea) which stated they could not take to the field until the full moon - at that time it was only the ninth day of the month - six days away. As the Spartans awaited it appears that Pheidippides then ran back to Athens and probably onto the battlefield at Marathon to convey the bad news.

\section{THE BATTLE PROPER}

Meanwhile the Athenians were drawn up on a piece of ground sacred to Heracles where they were joined by the Plateans (allies of the Athenians from the north) who came to support them with every available man (probably about 1000).

The Athenian generals were divided as to what tactics should be adopted but eventually Miltiades won the day and the decision to attack the Persians was made.

The Persians left their camp, marched south along the shore, crossed the bed of the Charadra river and formed a line of battle opposite the Greek position. For several days both armies faced each other without moving. The Greeks were probably waiting for the arrival of the Spartans whilst the Persians may have been hoping to keep the Greek army immobile tautology and meanwhile move a maritime force independently against an unguarded Athens.

The disposition of the Athenian troops before the battle was such that the centre was weakened by the effort to cover the whole Persian front; the wings were strong but the line in the centre was only a few ranks deep.

The Athenians suddenly advanced at a run towards the enemy who were about a mile away. The Persians felt it was suicidal madness for the Athenians to risk an assault with so small a force and rushing in with no support from either cavalry or archers.

The reason for the sudden attack is unknown - it was probably related to the return of Pheidippides and his attendant bad news, but it is also possible that the Persian cavalry (the most dangerous part of the expedition to the Athenians) embarked and the Athenians summarised that an attack on their undefended city was likely. Whatever the reason, the Athenians came on, closed with the enemy all along the line, and fought with a remarkable heroism.

They were the first Greeks to charge at a run, and the first who dared to look without flinching at Persian dress and the dreaded troops who wore it.

The struggle was long and drawn out. In the centre the advantage was with the Persians; but however the Athenians and the Plateans on the wings were both victorious. They drew both wings together into a single unit and chased the Persians in the centre, cutting them down until they came to the sea. 
The Athenians secured seven ships but the rest escaped and sailed out to sea. After picking up the Eretrian prisoners they had left on Aegilia, the Persians sailed around Cape Sunium towards Athens which they hoped to reach in advance of the Athenian army. Meanwhile, the Athenians hurried back and fixed their camp on a sacred site (once again to Heracles) at Cynosarges. When the Persian fleet appeared, it lay at anchor off Phalernum, realised the strength of the Greek defences, and then sailed back to Asia.

In the battle 6400 Persians were killed whereas the Athenian loss was only 192. They were later buried in a huge burial mound which is still present today. After the full moon 2000 Spartans set off for Marathon. They travelled so quickly that they only took three days to complete their journey. They had missed the battle but were very keen to see the bodies of dead Persians. That done, they complimented the Athenians on their good work and returned home to Sparta.

\section{CONCLUSION}

It seems fairly certain from all available historical evidence that an Athenian runner, whose name was probably Pheidippides, ran from Athens to Sparta and back, a distance of at least 280 miles in 3-4 days.

However, it is unlikely that he ran from Marathon to Athens after the battle and then cried out "Athens is saved" at the city gates before collapsing and dying. It is unlikely for at least two reasons.

First, the "Battle of Marathon" may have been won by the Athenians, but their home city of Athens was still gravely threatened by the Persians (who had only lost seven ships); whilst this was still so there was no good cause for rejoicing.

The second reason is that in the only contemporary historical text, Herodotus, there is no further mention of Pheidippides after his run to Sparta although the battle and the subsequent events are described by the old gossip in great detail.

The general misconceptions about the marathon are due to the popularity of a poem written in the middle of the Hellenic renaissance, by Robert Browning in 1879, entitled "Pheidippides". In this poem he tells the story of the Persian threat, Pheidippides' run to Sparta, his meeting with the god $P$ an, his return run to Marathon and the ensuing victory. He then merges this hero with the supposed bearer of the good news of victory; this unknown person may never have run let alone perished so dramatically.

It is probable that this poem, and not the actual historical facts, would have been in the minds of those, who not twenty years later, would be concerned with the revival of the Olympic Games and the formation of any possible events which could provide a link with the past.

The second last of the fifteen verses reads:

Unforseeing onel Yes he fought on the Marathon day: So when Persia was dust, all cried 'To Acropolis!

Run Pheidippides, one race more! The meed is thy due'. 'Athens is saved, thank Pan', go shoutl' He laying down his shield

Ran like fire once more: and the space twixt the fennel field

And Athens was stubble again, a field which a fire ran through

Till in he broke: 'Rejoice, we conquerl' Like wine through clay

Joy in his blood bursting his heart, he died - the bliss!

$$
\text { "Pheidippides" from "Dramatic Idyls" } 1879
$$

Once again the facts of history take second place to the romance of poetry and fiction.

\section{REFERENCES}

Bowra, M., Classical Greece, Time Life Books, Nederland, 1966.

Browning, R., The Poetical works of Robert Browning, OUP London, 1944.

Ehrenberg, V., From Solon to Socrates, Methuen, London, 1973.

Herodotus, The Histories, Penguin, London, 1972.

Maundell, R., The First Modern Olympics, University of Chicago Press, Los Angeles, 1976.

Wallechinsky, D., Wallace, I. and Wallace A., The Book of Lists, Corgi, London, 1978. 